\title{
CHOOSING A PROPER METHOD FOR STRENGTHENING WPC BEAMS WITH GROOVING METHOD USING SWARA-EDAS
}

\author{
Mahdi Chini ${ }^{1}$, Shahin Lale Arefi ${ }^{2}$, Sarfaraz Hashemkhani Zolfani ${ }^{3}$, Leonas \\ Ustinovicius $^{4}$
}

\begin{abstract}
Wood plastic composite (WPC) is a lightweight material, resistant against corrosion and damage, with recyclability of consuming materials. These materials usually used in marine structures frequently due to their unique features. In order to strengthen beams made by this material, usually Fibre-reinforced plastic (FRP) sheets are used, and one of the fracture modes in these beams is debonding of FRP sheet from the surface of the beams. To deal with this problem some grooves are used in the surface of the beam to improve the contact surface. The grooves include longitudinal, transverse and diagonal grooves. The main goal of this study is to assess different grooving methods in WPC-FRP beams. In this regard, primarily criteria (improving resistance, performance speed, performance complexity, performance costs, displacement and absorbing energy) were determined through interviews with experts in this field in order to assess the beams. Then, SWARA method employed to evaluate criteria with a policy based perspective and finally EDAS method applied for evaluating related alternatives. Based
\end{abstract}

\footnotetext{
${ }^{1}$ DSc., PhD., Eng., Road Housing and Urban Development Research Center (BHRC), Tehran, Iran, e-mail: M.chini@bhrc.ac.ir.

${ }^{2} \mathrm{PhD}$ student., Eng., Department of Civil Engineering, University of Mohaghegh Ardabili, Ardabil, Iran, e-mail: shahin.arefi@gmail.com.

${ }^{3}$ DSc., PhD., Eng., Amirkabir University of Technology (Tehran Polytechnic), Technology Foresight Group, Department of Management, Science and Technology, P.O. Box 1585-4413, Tehran, Iran, e-mail: sa.hashemkhani@gmail.com.

${ }^{4}$ Hab. dr., Prof., Eng., Department of Construction Management and Real Estate (VGTU), Vilnius, Lithuania, e-mail: leonas959@gmail.com.
} 
on obtained results, the longitudinal groove method is the best way of strengthening WPC beams to prevent debonding.

Keywords: Wood Plastic Composite (WPC); Debonding; Grooving; Fibre-reinforced plastic (FRP); Step-wise Weight Assessment Ratio Analysis (SWARA); Evaluation Based on Distance from Average Solution (EDAS)

\section{INTRODUCTION AND LITERATURE REVIEW}

Wood Plastic Composite (WPC) is a lightweight material, resistant against corrosion and damage, with recyclability of consuming materials that obtained from combination of wood and plastic scum. Typically, some materials such as steel, concrete and wood are used to build these structures and because they are always exposed to damages such as corrosion and erosion, retrofitting and replacement of some parts is done in order to insure their health and durability.

As a new brand material, WPC has been positively applying in so many construction uses and is created by mixture of wood (shape of sawdust) and polymeric resources [1-6].

Wangaard [7] as one of pioneers did a study on fiber-reinforced polymer used in wooden structures with both experimental and theoretical measures to investigate and compare the elastic deflection values of wood-fibreglass composite beams.

Haiar [8] has focused on characterizing Poly-Vinyl Chloride (PVC) and High Density Polyethylene (HDPE) WPC blends to use in structural applications. Nowadays, it can be seen in the literature that wooden structures reinforced with FRP composites have been applying in the different sub-fields of Civil Engineering such as bridges, railroad ties etc. [9-12].

In spite of the effective role of the FRP sheets that can be play in the flexural strengthening of the WPC elements, they have an important deficiency in the beam bonding. Consequently, early failure due to the de-bonding of beams, result in wastage of the beam designed capacity. In this regards, one of the previous researches by using some laboratory studies is carried out in order to present the main weakness of the FRP sheets in the surface un-bounding and the applicability and productivity of the FRP sheets with WPC materials [13]. Hence, combination of the FRP and WPC would enhance the performance and decrease the deficiencies simultaneously. 
Many researches in regarding of grooving method have done. Mostofinejad and Kashani [14] presented this method for the first time by concrete structure and also the research focused on postpone debonding of FRP Laminates in concrete beams and the results showed that by using grooving method debonding from the plate surface is delayed or completely prevented in most cases. Naghipour et al. [15] used longitudinal groove for attaching GFRP sheet to WPC surface. Finally, the result showed that the use of longitudinal grooves resulted in resistance improvement. Lale Arefi et al. [16] have evaluated the grooving method including various shapes such as diagonal grooves, transverse grooves and longitudinal grooves, in the debonding control of beams reinforced by FRP sheets; compare their treatment such as Force-displacement diagram; determine the failure mode and the ultimate failure load by changing the width, depth, and shapes of grooves; and determine the number of reinforcement layers.

When FRP sheets are used to strengthen the reinforced concrete beams, efficiency of different confinement methods such as Externally Bounded Reinforcement (EBR) and Externally Bounded Reinforcement On Grooves (EBROG), in different flexural failure mechanisms are investigated in the previous studies [17; 18]. This research examined many samples in laboratory and finally showed that using the grooving method leads to increased ultimate load carrying capacity in the beams, also. Mostofinejad et al. [19] investigated on EBROG and EBRIG methods in reinforcement concrete beams that involved FRP sheets. The considerated specimens were subjected under flexural loading. Finally result showed the capacity load in EBROG and EBRIG method compared to EBR method was increased.

Moshiri et al. [20] have done researches on strengthening of reinforcement concrete columns by using of grooving method. They showed that using grooving method postponed the CFRP sheets from concrete surface.

Mostofinejad and Torabian [21] conducted experimentally research works on circular reinforcement concrete columns strengthened with longitudinal CFRP composites. They compared EBR and EBROG methods in their researches. Finally, the result demonstrated that in the columns strengthened with longitudinal FRP sheets using the EBROG method, improved the load-carrying capacity.

Mostofinejad and Akhlaghi [22] conducted a research on efficiency of grooving method in reinforcement beam-column joints that strengthened with CFRP sheets. The result showed using grooving method in this structure was able to eliminate altogether the debonding failure mode and remarkable improvement.

One of the fundamental problems in beams strengthened by FRP sheet is the premature failure that leads to sudden debonding of the sheets before reaching their ultimate strength. The main reason of 
this early failure is unsuitable surface preparation on beams that FRP composite is installed. Accordingly, preparation is needed to be done before connecting the FRP composite to WPC for eliminating poor surfaces and making an appropriate structure in FRP installation.

Among the failure modes, WPC delamination is one of the most prominent types of failure that increases the importance of further studies on this subject. The main goal of this research is to identify and provide a variety of methods of strengthening WPC and also choose the proper method to prevent sheets from debonding with considering of construction management.

In this regard, in addition to considering the resistance index, other indicators have also been considered. Schematic presentation of the processes of this study is illustrated in Figure 1.



Fig. 1. Schematic presentation of WPC beam selection process

\section{METHODOLOGY}

In this study, first of all, literature review and references apply to evaluate various methods of strengthening WPC beams in order to prevent debonding of the FRP sheets. Then, all of the proposed 
criteria are extracted by interviewing experts in the field of construction management, structural engineering and economic experts to assess the best method of strengthening WPC beams (Table 1). Next, a questionnaire was presented to 21 experts to obtain their ideas in weighing effective criteria based on SWARA method; and finally alternatives will evaluate according to the EDAS methodology. SWARA-EDAS hybrid MADM method is a new-brand hybrid MADM method which is developed in this study as the main framework and methodology of the research. Juodagalviene et al. [23] was the only case which applied SWARA-EDAS together for house's plan shape in practice. EDAS background will help to have more stable answers and SWARA like previous studies will be helpful in evaluating criteria based on policy based strategy and perspective.

Table 1. Background Information of Experts

\begin{tabular}{|c|c|c|}
\hline Fields & Education Background & NO \\
\hline \multirow{3}{*}{ Construction Management } & Bachelor & - \\
\cline { 2 - 3 } & Master & 3 \\
\cline { 2 - 3 } & PhD & 4 \\
\hline \multirow{3}{*}{ Economic } & Bachelor & - \\
\cline { 2 - 3 } & Master & - \\
\cline { 2 - 3 } & PhD & - \\
\hline \multirow{3}{*}{ Structural Engineer } & Bachelor & 5 \\
\cline { 2 - 3 } & Master & - \\
\cline { 2 - 3 } & PhD & 1 \\
\hline \multirow{3}{*}{ Top Managers } & Bachelor & 1 \\
\cline { 2 - 3 } & Master & \\
\cline { 2 - 3 } & PhD & \\
\cline { 2 - 3 } & & \\
\end{tabular}

\subsection{SWARA METHOD}

SWARA is a MADM method which is unique in its application. SWARA is useful to be applied for evaluating criteria and relative weights [24;25]. Although SWARA is working the same as what AHP [26], ANP [27], FARE [28] and BWM [29] can do, the structure and perspective is almost different. SWARA is a policy based MADM method which is working based on priorities and policies in different levels of decision making process. In those cases which policies are in top of priority, SWARA method can be really helpful. For the first step as a SWARA methodology step, criteria should be ranked and prioritized based on policies and experts' opinions and this issue is special advantage of this method $[30 ; 31]$.

Recently, SWARA has been applied in so many other studies such as:

- Assessing building projects regarding to environmental sustainability [32].

- Assessing process of chemical wastewater purification [33].

- Analyzing LARG supply chain management competitive strategies [34]. 
- Assessment of light supply in the public underground safe spaces [35].

- Evaluation of the vulnerability of office buildings [36].

- Personnel selection [37].

- Evaluating companies [38].

- Selection of green suppliers [39].

- Selection of candidates in the mining industry [40].

- Technology Foresight about R\&D Projects Selection [41].

- Planning the priority of high tech industries [42].

- Structural health monitoring of bridges [43].

\subsection{EDAS METHOD}

This method has introduced recently and has an application the same as some older MADM methods such as: VIKOR, TOPSIS, COPRAS, and WASPAS etc. [44]. EDAS isn't the only new MADM method which is proposed in the new decade and some other such as WASPAS [45], CODAS [46] have introduced recently. The main idea of this new method it is not far from some other methods such as TOPSIS and VIKOR.

The main difference of EDAS is the answer of distance from average solution (AV) and main items are positive distance from average (PDA), and the negative distance from average (NDA). These items measures of differences of each alternative (solution or answer) and the average solution. Eventually, higher values of PDA and lower values of NDA will indicate optimal solution.

Recently, EDAS has been applied in so many other studies such as:

- Extended EDAS Based on Interval Grey Numbers [47].

- Evaluation of a Safe Built Environment due to Sustainable Development (SD) Values [48].

- An extended group EDAS [49].

- Group extended EDAS [50].

- Solid waste disposal site selection [51].

\section{DETERMINE EFFECTIVE CRITERIA ON THE PROCESS OF SELECTION}

Effective criteria were identified by doing interviews and getting ideas of experts to select strengthening methods by grooving; decision making criteria include a set of economic and 
administrative characteristics, which are presented in Table 2.

Table 2: Criteria influencing on strengthening WPC beam by grooving

\begin{tabular}{lcc}
\hline \multicolumn{2}{c}{ Proposed indicators for evaluating different methods of strengthening by grooving } \\
\hline $\mathrm{C}_{1}$ & Improving resistance & Max \\
$\mathrm{C}_{2}$ & Performance speed & Max \\
$\mathrm{C}_{3}$ & Performance complexity & Min \\
$\mathrm{C}_{4}$ & Performance costs & Min \\
$\mathrm{C}_{5}$ & Displacement & Min \\
$\mathrm{C}_{6}$ & Absorbing energy & Max \\
\hline
\end{tabular}

\section{GROOVING METHODS ON REINFORCEMENT OF WPC-FRP BEAMS}

There are five common grooving methods in reinforcement of WPC beams with FRP sheet as follows (Figure 2):

- Longitudinal groove (A1)

- Transverse groove (A2)

- Without surface preparation (A3)

- With surface preparation (A4)

- Diagonal groove (A5)

Longitudinal grooves are more resistant than other grooves because of the paralleled stress under the beam with longitudinal grooves and creating a proper surface between WPC surface and FRP sheet; it maximizes the strain of FRP sheets, and a beam with higher flexural capacity will be created. Strength of beams made by a diagonal groove is higher than the beams made by a transverse groove. Performance speed of longitude grooves is higher and it has less complexity than diagonal grooves, but it has less speed and higher complexity than the transverse grooves.

Considering the costs, the cost of the longitudinal groove is higher than transverse groove but it has a much lower cost comparing to the diagonal groove. 


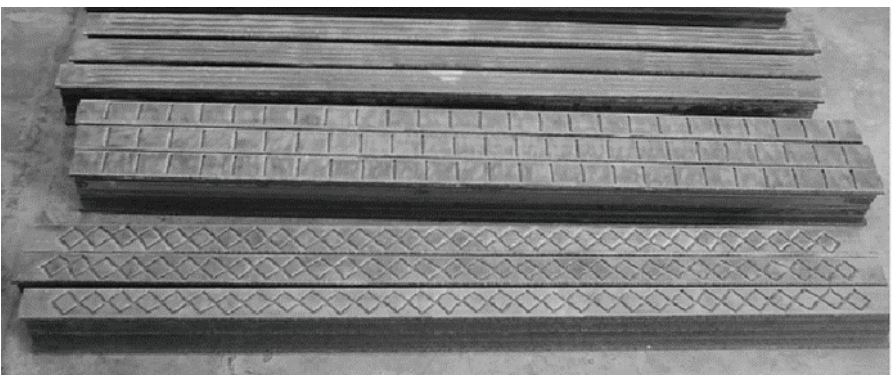

Fig. 2. Different shapes of grooves [13]

\section{HIERARCHICAL TREE}

The hierarchical tree is a graphical display of the issue (goal, criteria, and selecting options) (Figure $3)$.



Fig. 3. Graphical hierarchy tree of selecting the optimal method of grooving

\section{RESULTS FOR EVALUATING CRITERIA BASED ON SWARA}

Due to methodology which is presented previously, calculations and final results for evaluating criteria are presented in Table 3. Based on methodological steps, this section has finished in 2 main steps. First of all, prioritizing criteria based on policies and eventually, the process of weighting. 
Table 3. Criteria's evaluation based on SWARA method

\begin{tabular}{c|c|c|c|c}
\hline Criterion & $\begin{array}{c}\text { Comparative } \\
\text { importance of } \\
\text { average value } \\
s_{j}\end{array}$ & $\begin{array}{c}\text { Coefficient } \\
k_{j}=s_{j}+1\end{array}$ & $\begin{array}{c}\text { Recalculated } \\
\text { weight } \\
w_{j}=\frac{x_{j-1}}{k_{j}}\end{array}$ & $\begin{array}{c}\text { Weight } \\
q_{j}=\frac{w_{j}}{\sum w_{j}}\end{array}$ \\
\hline $\mathrm{C}_{1}$ & 0.22 & 1 & 1 & 0.268 \\
\hline $\mathrm{C}_{5}$ & 0.26 & 1.22 & 0.651 & 0.175 \\
\hline $\mathrm{C}_{4}$ & 0.24 & 1.26 & 0.525 & 0.141 \\
\hline $\mathrm{C}_{6}$ & 0.32 & 1.32 & 0.397 & 0.107 \\
\hline $\mathrm{C}_{3}$ & 0.19 & 1.19 & 0.334 & 0.090 \\
\hline $\mathrm{C}_{2}$ & & & & 0.220 \\
\hline
\end{tabular}

According to the results of SWARA method, improving resistance got the highest attention and weight and the priority for other criteria is as follows: displacement, performance costs, absorbing energy, performance complexity and performance speed.

\section{RESULTS FOR EVALUATING CRITERIA BASED ON EDAS}

Five probable solutions as alternatives are evaluated here, in this section, based on EDAS methodology. The process, information and final evaluation based on EDAS method is presented in table 4-9.

Table 4. Decision making matrix about strengthening WPC beams with grooving method

\begin{tabular}{|c|c|c|c|c|c|c|}
\hline & $\mathrm{C}_{1}$ & $\mathrm{C}_{2}$ & $\mathrm{C}_{3}$ & $\mathrm{C}_{4}$ & $\mathrm{C}_{5}$ & $\mathrm{C}_{6}$ \\
\hline Preferable & $\mathrm{Max}$ & $\mathrm{Max}$ & $\mathrm{Min}$ & $\mathrm{Min}$ & $\mathrm{Min}$ & Max \\
\hline Weights & 0.268 & 0.090 & 0.107 & 0.175 & 0.220 & 0.141 \\
\hline $\mathrm{A}_{1}$ & 5.80 & 8 & 4 & 3 & 16.53 & 5 \\
\hline $\mathrm{A}_{2}$ & 6.75 & 7 & 4 & 4 & 17.03 & 6 \\
\hline $\mathrm{A}_{3}$ & 6.78 & 6 & 5 & 5 & 19.77 & 8 \\
\hline $\mathrm{A}_{4}$ & 6.52 & 7 & 6 & 4 & 18.17 & 7 \\
\hline $\mathrm{A}_{5}$ & 6.21 & 5 & 7 & 6 & 17.37 & 7 \\
\hline
\end{tabular}

Table 5. Results for Positive Distance from Average (PDA)

\begin{tabular}{|c|c|c|c|c|c|c|}
\hline & $\mathrm{C}_{1}$ & $\mathrm{C}_{2}$ & $\mathrm{C}_{3}$ & $\mathrm{C}_{4}$ & $\mathrm{C}_{5}$ & $\mathrm{C}_{6}$ \\
\hline Weights & 0.268 & 0.090 & 0.107 & 0.175 & 0.220 & 0.141 \\
\hline $\mathrm{A}_{1}$ & 0.000 & 0.212 & 0.231 & 0.318 & 0.000 & 0.000 \\
\hline $\mathrm{A}_{2}$ & 0.053 & 0.061 & 0.231 & 0.091 & 0.000 & 0.000 \\
\hline $\mathrm{A}_{3}$ & 0.057 & 0.000 & 0.038 & 0.000 & 0.112 & 0.212 \\
\hline $\mathrm{A}_{4}$ & 0.017 & 0.061 & 0.000 & 0.091 & 0.022 & 0.061 \\
\hline $\mathrm{A}_{5}$ & 0.000 & 0.000 & 0.000 & 0.000 & 0.000 & 0.061 \\
\hline
\end{tabular}


Table 6. Results for Negative Distance from Average (NDA)

\begin{tabular}{|c|c|c|c|c|c|c|}
\hline & $\mathrm{C}_{1}$ & $\mathrm{C}_{2}$ & $\mathrm{C}_{3}$ & $\mathrm{C}_{4}$ & $\mathrm{C}_{5}$ & $\mathrm{C}_{6}$ \\
\hline Weights & 0.268 & 0.090 & 0.107 & 0.175 & 0.220 & 0.141 \\
\hline $\mathrm{A}_{1}$ & 0.095 & 0.000 & 0.000 & 0.000 & 0.070 & 0.242 \\
\hline $\mathrm{A}_{2}$ & 0.000 & 0.000 & 0.000 & 0.000 & 0.042 & 0.091 \\
\hline $\mathrm{A}_{3}$ & 0.000 & 0.091 & 0.000 & 0.136 & 0.000 & 0.000 \\
\hline $\mathrm{A}_{4}$ & 0.000 & 0.000 & 0.154 & 0.000 & 0.000 & 0.000 \\
\hline $\mathrm{A}_{5}$ & 0.032 & 0.242 & 0.346 & 0.364 & 0.023 & 0.000 \\
\hline
\end{tabular}

Table 7. Sum of Weighted PDA

\begin{tabular}{|c|c|c|c|c|c|c|}
\hline & $\mathrm{C}_{1}$ & $\mathrm{C}_{2}$ & $\mathrm{C}_{3}$ & $\mathrm{C}_{4}$ & $\mathrm{C}_{5}$ & $\mathrm{C}_{6}$ \\
\hline $\mathrm{A}_{1}$ & 0.000 & 0.047 & 0.040 & 0.045 & 0.000 & 0.000 \\
\hline $\mathrm{A}_{2}$ & 0.014 & 0.013 & 0.040 & 0.013 & 0.000 & 0.000 \\
\hline $\mathrm{A}_{3}$ & 0.015 & 0.000 & 0.007 & 0.000 & 0.012 & 0.019 \\
\hline $\mathrm{A}_{4}$ & 0.005 & 0.013 & 0.000 & 0.013 & 0.002 & 0.005 \\
\hline $\mathrm{A}_{5}$ & 0.000 & 0.000 & 0.000 & 0.000 & 0.000 & 0.005 \\
\hline
\end{tabular}

Table 8 . Sum of weighted NDA

\begin{tabular}{|c|c|c|c|c|c|c|}
\hline & $\mathrm{C}_{1}$ & $\mathrm{C}_{2}$ & $\mathrm{C}_{3}$ & $\mathrm{C}_{4}$ & $\mathrm{C}_{5}$ & $\mathrm{C}_{6}$ \\
\hline $\mathrm{A}_{1}$ & 0.026 & 0.000 & 0.000 & 0.000 & 0.007 & 0.022 \\
\hline $\mathrm{A}_{2}$ & 0.000 & 0.000 & 0.000 & 0.000 & 0.004 & 0.008 \\
\hline $\mathrm{A}_{3}$ & 0.000 & 0.020 & 0.000 & 0.019 & 0.000 & 0.000 \\
\hline $\mathrm{A}_{4}$ & 0.000 & 0.000 & 0.027 & 0.000 & 0.000 & 0.000 \\
\hline $\mathrm{A}_{5}$ & 0.008 & 0.053 & 0.061 & 0.051 & 0.002 & 0.000 \\
\hline
\end{tabular}

Table 9. Normalized values (NSP, NSN) and ranking

\begin{tabular}{|c|c|c|c|c|}
\hline & NSP & NSN & AS & Rank \\
\hline $\mathrm{A}_{1}$ & 1.000 & 0.688 & 0.844 & 1 \\
\hline $\mathrm{A}_{2}$ & 0.612 & 0.928 & 0.770 & 2 \\
\hline $\mathrm{A}_{3}$ & 0.404 & 0.777 & 0.590 & 3 \\
\hline $\mathrm{A}_{4}$ & 0.292 & 0.847 & 0.569 & 4 \\
\hline $\mathrm{A}_{5}$ & 0.041 & 0.000 & 0.021 & 5 \\
\hline
\end{tabular}

According to the result which is extracted from table 10 and EDAS method, Longitude groove ranked as the best alternative and generally priority is as follows:

1. Longitude groove

2. Transverse groove

3. Without surface preparation

4. With surface preparation

5. Diagonal groove 


\section{CONCLUSION}

As pointed out earlier, there are five common methods of grooving used to prevent debonding of FPR in WPC beams. To evaluate this method of grooving, six criteria were considered according to experts' ideas. In this research, as it mentioned, 21 experts participated in the process of research which covered both sides of methodologies and results.

SWARA as a policy based MADM method, applied for evaluating criteria and weighting them. From the outputs of SWARA method, more important policies and decisions illustrated as follows: improving resistance considered as the most critical and important criterion for evaluating alternatives. After that, displacement, performance cost, absorbing energy, performance complexity and performance speed placed as the policies (decisions) in their priority.

Grooving methods as alternatives for this decision making challenge evaluated by EDAS method which is a new brand MADM method. Based on results all five alternatives prioritized and ranked as follows: 1 . Longitude groove; 2 . Transverse groove; 3 . Without surface preparation; 4 . With surface preparation; 5. Diagonal groove.

As it presented in this article, another contribution of this study was presenting new hybrid MADM method which is completely practical and user friendly for managers and policy makers. SWARAEDAS can be applied in other research studies in the future when researchers need an area to consider more policies instead of just classical decision making system and moderate-conservative and reliable answers.

\section{REFERENCES}

1. Jam N. Jafarian, A. H. Behravesh, "Flow Behavior of HDPE-Fine Wood Particles Composites", Journal of Thermoplastic Composite Materials 20(5): 439-451, 2007.

2. Jam N. Jafarian, A. H. Behravesh, "Challenge to the Production of Fine Wood-Plastic Injection Molded Composites", Journal of Reinforced Plastics and Composites 28(1): 73-82, 2009.

3. J. Markarian, "Material and processing developments drive wood-plastic composites forward", Plastics, Additives and Compounding 5(4): 24-26, 2003.

4. A. Wechsler, S. Hiziroglu, "Some of the properties of wood-plastic composites", Building and Environment 42(7): 2637-2644, 2007.

5. G. Pritchard, "Two technologies merge: wood plastic composites", Reinforced Plastics 48(6): 26-29, 2004.

6. O. Gunes, O. Buyukozturk, E. Karaca, „A fracture-based model for FRP debonding in strengthened beams”, Engineering Fracture Mechanics 76(12): 1897-1909, 2009.

7. F. F. Wangaard, "Elastic deflection of wood-fiberglass composite beams", Forest Products Journal 14(6): 256$260,1964$.

8. K. J. Haiar, "Performance and design of prototype wood-plastic composite section", Department of Civil and Environmental Engineering (Master thesis), Washington State University, Pullman (WA), 2000.

9. J. R. Gilfillan, S. G. Gilbert, G. R. H. Patrick, "The Use of FRP Composites in Enhancing the Structural Behavior of Timber Beams", Journal of Reinforced Plastics and Composites 22(15): 1373-1388, 2003.

10. A. Borri, M. Corradi, A. Grazini, "A method for flexural reinforcement of old wood beams with CFRP materials", Composites Part B: Engineering 36(2): 143-153, 2005. 
11. R. Lopez-Anido, A. P. Michael, T. C. Sandford, "Experimental characterization of FRP composite-wood pile structural response by bending tests", Marine Structures 16(4) ; 257-274, 2003.

12. C. P. Pantelides, P. Romero, L. D. Reaveley, "Rehabilitation of splice connections of wood trusses with FRP composites", Construction and Building Materials 24(1): 37-45, 2010.

13. M. Naghipour, M. Nematzadeh, Q. Yahyazadeh, "Analytical and experimental study on flexural performance of WPC-FRP beams", Construction and Building Materials 25(2): 829-837, 2011.

14. D. Mostofinejad, A. T. Kashani, "Experimental study on effect of EBR and EBROG methods on debonding of FRP sheets used for shear strengthening of RC beams", Composites: Part B 45: 1704-1713, 2013.

15. M. Naghipour, Arefi S. Lale, M. Nematzadeh, "Performance of longitudinal grooves to prevent debonding of GFRP sheets used for the reinforcement of WPC beams", European Journal of Environmental and Civil Engineering 17(9): 761-776, 2013.

16. Arefi, S. Lale, M. Naghipour, Z. Turskis, M. Nematzadeh, "Evaluation of grooving method to postpone debonding of FRP laminates in WPC-FRP beams", Journal of Civil Engineering and Management 20(2): 237 246, 2014.

17. D. Mostofinejad, A. Moghaddas, "Bond efficiency of EBR and EBROG methods in different flexural failure mechanisms of FRP strengthened RC beams", Construction and Building Materials 54: 605-614, 2014.

18. D. Mostofinejad, E. Mahmoudabadi, "Grooving as Alternative Method of Surface Preparation to Postpone Debonding of FRP Laminates in Concrete Beams", Journal of Composites for Construction 14(6) https://doi.org/10.1061/(ASCE)CC.1943-5614.0000117, (2010).

19. D. Mostofinejad, S. M. Shameli, A. Hosseini, "EBROG and EBRIG methods for strengthening of RC beams by FRP sheets", European Journal of Environmental and Civil Engineering 18(6): 652-668, 2014.

20. N. Moshirim, A. Hosseini, D. Mostofinejad, "Strengthening of RC columns by longitudinal CFRP sheets: Effect of strengthening technique". Construction and Building Materials 79 (2015): 318-325, 2015.

21. D. Mostofinejad, A. Torabian, "Experimental Study of Circular RC Columns Strengthened with Longitudinal CFRP Composites under Eccentric Loading: Comparative Evaluation of EBR and EBROG Methods", Journal of Composites for Construction 20(2): 04015055-1:15, 2016.

22. D. Mostofinejad, A. Akhlaghi, "Efficiency of Grooving Method Used for Deficient RC Beam-Column Joints Seismically Rehabilitated with CFRP Sheets", High Tech Concrete: Where Technology and Engineering Meet, Springer, 849-857, 2017.

23. B. Juodagalviené, Z. Turskis, J. Saparauskas, A. "Endriukaityte, Integrated multi-criteria evaluation of house's plan shape based on the EDAS and SWARA methods", Engineering Structures and Technologies 9(3): 117-125, 2017.

24. Zolfani S. Hashemkhani, J. Saparauskas, "New Application of SWARA Method in Prioritizing Sustainability Assessment Indicators of Energy System”, Inzinerine Ekonomika-Engineering Economics 24(5): 408-414, 2013.

25. D. Stanujkic, D. Karabasevic, E. K. Zavadskas, "A framework for the Selection of a packaging design based on the SWARA method", Inzinerine Ekonomika-Engineering Economics 26(2): 181-187, 2015.

26. T. L. Saaty, “The Analytic Hierarchy Process: Planning, Priority Setting, Resources Allocation”, London, McGraw-Hill, 1980.

27. T. L. Saaty, "Decision making with dependence and feedback: the analytic network process", Pittsburgh, PA: RWS Publications, 2001.

28. R. Ginevicius, "A new determining method for the criteria weights in multi-criteria evaluation", International Journal of Information Technology \& Decision Making 10(6): 1067-1095, 2011.

29. J. Rezaei, "Best-worst multi-criteria decision-making method", Omega 53: 49-57, 2015.

30. R. Haghnazar Kouchaksaraei, Zolfani S. Hashemkhani, M. Golabchi, "Glasshouse locating based on SWARACOPRAS approach", International Journal of Strategic Property Management 19(2): 111-122, 2015.

31. M. Vafaeipour, Zolfani S. Hashemkhani, Varzandeh M. H. Morshed, A. Derakhti, Eshkalag M. "Keshavarz, Assessment of regions priority for implementation of solar plants in Iran: New application of a hybrid multicriteria decision making approach", Energy Conversion and Management 86: 653-663, 2014.

32. Zolfani S. Hashemkhani, M. Pourhossein, M. Yazdani, E. K. Zavadskas, "Evaluating construction projects of hotels based on environmental sustainability with MCDM framework", Alexandria Engineering Journal, https://doi.org/10.1016/j.aej.2016.11.002, 2017. (In press).

33. M. R. Khodadadi, Zolfani, S. Hashemkhani, M. Yazdani, E. K. Zavadskas, "A hybrid MADM analysis in evaluating process of chemical wastewater purification regarding to advance oxidation processes", Journal of Environmental Engineering and Landscape Management 25(3): 277-288, 2017.

34. Asl G. Karimi, E. Karimi, Zolfani, S. Hashemkhani, J. Saparauskas, "Analyzing LARG supply chain management co mpetitive strategies in Iranian cement industries”, E+M Ekonomie a Management 20(3): 70-83, 2017.

35. J. Nakhaei, Arefi S. Lale, M. Bitarafan, S. Kildiene, "Evaluation of light supply in the public underground safe spaces by using of COPRAS-SWARA methods", International Journal of Strategic Property Management 20(2): 198-206, 2016 
36. J. Nakhaei, M. Bitarafan, Arefi S. Lale, O. Kapliński, "Model for rapid assessment of vulnerability of office buildings to blast using SWARA and SMART methods (a case study of swiss re tower)", Journal of Civil Engineering and Management 22 (6): 831-843, 2016.

37. D. Karabasevic, E. K. Zavadskas, Z. Turskis, D. Stanujkic, "The framework for the selection of personnel based on the SWARA and ARAS methods under uncertainties", Informatica 27(1): 49-65, 2016.

38. D. Karabasevic, J. Paunkovic, D. Stanujkic, „Ranking of companies according to the indicators of corporate social responsibility based on SWARA and ARAS methods", Serbian Journal of Management 11(1): 43-53, 2016.

39. M. Yazdani, Zolfani S.Hashemkhani, E. K. Zavadskas, "New integration of MCDM methods and QFD in the selection of green suppliers", Journal of Business Economics and Management 17(6): 1097-1113, 2016.

40. D. Karabasevic, D. Stanujkic, S. Urosevic, M. Maksimovic, "Selection of candidates in the mining industry based on the application of the SWARA and the MULTIMOORA methods", Acta Montanistica Slovaca: 20(2), 116-124, 2015.

41. Hashemkhani Zolfani, S., Salimi, J., Maknoon, R., Kildiene, S. (2015). Technology Foresight About R\&D Projects Selection; Application of SWARA Method at the Policy Making Level, Inzinerine EkonomikaEngineering Economics, 26(5), 571-580.

42. M. R. Ghorshi Nezhad, Zolfani S. Hashemkhani, F. Moztarzadeh, E. K. Zavadskas, M. Bahrami, "Planning the priority of high tech industries based on SWARA-WASPAS methodology: The case of the nanotechnology industry in Iran", Economic Research-Ekonomska Istraživanja 28(1): 1111-1137, 2015.

43. M. Bitarafan, S. Hashemkhani Zolfani, S. Lale Arefi, E. K. Zavadskas, A. Mahmoudzadeh, "Evaluation of realtime intelligent sensors for structural health monitoring of bridges based on SWARA-WASPAS; a case in Iran", The Baltic Journal of Road and Bridge Engineering 9(4): 333-340, 2014.

44. M. Keshavarz Ghorabaee, E. K. Zavadskas, L. Olfat, Z. Turskis, "Multi-Criteria Inventory Classification Using a New Method of Evaluation Based on Distance from Average Solution (EDAS)", Informatica 26(3): 435-451, 2015.

45. E. K. Zavadskas, Z. Turskis, J. Antucheviciene, A. Zakarevicius, "Optimization of weighted aggregated sum product assessment”, Electronics and Electrical Engineering (6): 3-6, (2012).

46. Ghorabaee M. Keshavarz, E. K. Zavadskas, Z. Turskis, J. Antucheviciene, "A new combinative distance-based assessment (CODAS) method for multi-criteria decision-making”, Economic Computation and Economic Cybernetics Studies and Research 50(3): 25-44, 2016.

47. D. Stanujkic, E. K. Zavadskas, Ghorabaee, M. Keshavarz, Z. Turskis, “An Extension of the EDAS Method Based on the Use of Interval Grey Numbers", Studies in Informatics and Control 26(1), 5-12, 2017.

48. E. K. Zavadskas, F. Cavallaro, V. Podvezko, U. Ubarte, A. Kaklauskas, "MCDM Assessment of a Healthy and Safe Built Environment According to Sustainable Development Principles: A Practical Neighborhood Approach in Vilnius", Sustainability 9(702), doi:10.3390/su9050702, 2017.

49. Ghorabaee M. Keshavarz, M. Amiri, E. K. Zavadskas, Z. Turskis, "Multi-Criteria group decision-making using an extended EDAS method with interval Type-2 fuzzy sets", E\&M Economics and Management 20(1): 48-68, 2017.

50. E. Trinkūnienėa, V. Podvezko, E. K. Zavadskas, I. Jokšienè, I. Vinogradova, V. Trinkūnas, "Evaluation of quality assurance in contractor contracts by multi-attribute decision-making methods", Economic ResearchEkonomska Istraživanja 30(1): 1152-1180, 2017.

51. C. Kahraman, Ghorabaee M. Keshavarz, E. K. Zavadskas, Onar S. Cevik, M. Yazdani, B. Oztaysi, "Intuitionistic fuzzy EDAS method: an application to solid waste disposal site selection", Journal of Environmental Engineering and Landscape Management 25(1): 1-12, 2017. 


\section{LIST OF FIGURES AND TABLES:}

Fig. 1. Schematic presentation of WPC beam selection process

Fig. 2. Different shapes of grooves

Fig. 3. Graphical hierarchy tree of selecting the optimal method of grooving

Table 1. Background Information of Experts

Table 2. Criteria influencing on strengthening WPC beam by grooving

Table 3. Criteria's evaluation based on SWARA method

Table 4. Decision making matrix about strengthening WPC beams with grooving method

Table 5. Results for Positive Distance from Average (PDA)

Table 6. Results for Negative Distance from Average (NDA)

Table 7. Sum of Weighted PDA

Table 8. Sum of weighted NDA

Table 9. Normalized values (NSP, NSN) and ranking 